\title{
Glucocorticoid receptor (DIGR1) is expressed in pre-larval and larval stages of the teleost fish Dicentrarchus labrax
}

\author{
M. L. Di Bella • M. Vazzana • A. Vizzini • N. Parrinello
}

Received: 8 October 2007 /Revised: 15 February 2008 / Accepted: 18 February 2008 / Published online: 8 May 2008

(C) The Author(s) 2008

\begin{abstract}
Glucocorticoid hormone receptors (GR), members of the nuclear hormone receptor superfamily, are ligand-dependent transcription factors expressed in various tissues by binding to specific DNA sequences. Since glucocorticoids have a role in maintaining the homeostatic status in fish, we previously cloned and sequenced a GR (DlGR1) of adult Dicentrarchus labrax; we also showed mRNA expression (in situ hybridization) and tissue immunohistochemical localization of DlGR1 in several organs. This work has now been extended to the examination of the expression, tissue distribution, and cytolocalization of DlGR1 in larval developmental stages by similar methods to those used for the adult organs. The riboprobe included the DIGR1 cDNA transcriptional activation domain (1.0-1,300 nucleotide sequence) showing no significant similarity with a known second GR cDNA sequence of sea bass. The antibody was specific for an opportunely selected peptide sequence of the DlGR1 transcriptional domain. In histological sections of brain, head kidney, gills, liver, anterior intestine, and spleen cells, the riboprobe was mainly located in the cell nucleus. The antibody identified DIGR1 in the head kidney, gills, liver, and anterior intestine, mainly located in the cytosol. These results are in agreement with the receptor location in adult
\end{abstract}

This work was supported by a research grant from the University of Palermo.

M. L. Di Bella $\cdot$ M. Vazzana $\cdot$ A. Vizzini $\cdot$ N. Parrinello $(\triangle)$

Laboratory of Marine Immunobiology,

Department of Animal Biology, University of Palermo,

Via Archirafi 18,

90123 Palermo, Italy

e-mail: nicpar@unipa.it tissues. The greater presence of both the transcript and protein of DlGR1 in the late developmental stages suggests an increasing expression of this receptor. The cytolocalization (nuclear-cytosolic) and presumptive roles of DIGR1containing tissues are discussed.

Keywords Larval development - Glucocorticoid receptor. In situ hybridization $\cdot$ Immunohistochemistry .

Dicentrarchus labrax (Teleostei)

\section{Introduction}

In teleost fishes, cortisol is the main corticosteroid secreted by the interrenal cells of the head-kidney under the control of the hypothalamus-pituitary-interrenal axis (Reid et al. 1996) and exerts a central role in several physiological actions (Mommsen et al. 1999; de Jesus et al. 1991; de Jesus and Hirano 1992; Vazzana et al. 2002). The effects of cortisol can be mediated through intracellular receptors that act as ligand-dependent transcription factors. Because of its lipophilic nature, cortisol enters into the cells by passive diffusion and, once inside the cells, binds to a glucocorticoid receptor (GR) (Ducouret et al. 1995) with a cytoplasmic versus nuclear distribution (Kumar et al. 2006).

As in mammals where two forms of receptor (GR $\alpha$ and GR $\beta$ ) are produced by alternative translation of the same gene (Yudt and Chidlowski 2002), some teleost fishes possess different isoforms of the GR. Oncorhynchus mykiss (Ducouret et al. 1995; Takeo et al. 1996; Bury et al. 2003) and Haplocrhomis burtoni (Greenwood et al. 2003) have two different GR genes that encode receptor protein with high amino acid sequence identity, especially for the Cterminal part. They encode different isoforms showing 
different expression patterns in tissues (brain, head kidney, spleen, gill, muscle, and liver) and different transactivation properties. Moreover, they differ in their affinity for cortisol and are functionally distinct in their actions on classical GR-sensitive promoters (Stolte et al. 2006).

From the liver tissue of the sea bass Dicentrarchus labrax, Terova et al. (2005) have cloned and sequenced a GR of 2457 bp (NCBI Gene Bank accession no. AY549305) that encodes an 818-amino-acid protein. Following a previous NCBI Gene Bank registration (accession no. AY619996), Vizzini et al. (2007) have published the isolated and sequenced cDNA (2592 bp) of leukocytes taken from the peritoneal cavity of the sea bass; this cDNA encodes a GR that they have named DlGR1. The complete sequences of GR (Terova et al. 2005) and DlGR1 display high amino acid sequence identity ( $83 \%$, BLASTN), but no significant sequence similarity has been found at the transcriptional activation domain. DlGR1 appears to be expressed in cells isolated from the peritoneal cavity as shown by in situ hybridization assay (ISH). Finally, Vazzana et al. (2008) have reported that, in adult sea bass, DlGR1 transcript (ISH) and protein (immunohistochemistry) are present in head kidney, spleen, anterior intestine, gills, and heart.

In fish, data concerning the cytolocalization of GR in tissues of developmental stages are lacking, whereas the role of the receptor ligand, i.e., cortisol, has been emphasized. In a variety of fishes, measurements of the cortisol content support the importance of this hormone in development and metamorphosis (Barry et al. 1995; Feist and Schreck 2002; Deane and Woo 2003; Yeoh et al. 1996). During early larval development, cortisol regulates osmoregulatory function (Ayson et al. 1995; Lin et al. 1999) and has a role in the metamorphosis or direct development from larvae to juveniles (Kim and Brown 1997; Deane and Woo 2003). In juvenile O. mykiss, studies carried out by using synthetic glucocorticoids have shown that GR has the same tissue distribution as that observed in adults (Maule and Schreck 1990) including the hypothalamus, leukocytes, and erythrocytes (Pottinger and Brierley 1997; Allison and Omeljaniuk 1998).

In the present paper, the GR expression and localization in post-hatching larvae is shown for the first time. ISH with the specific riboprobe used in previous research (Vizzini et al. 2007; Vazzana et al. 2008) has revealed that the DlGR1 gene is expressed in brain, head kidney, spleen, anterior intestine, liver, and gills, reaching higher expression levels in juveniles. In addition, immunohistochemical studies with a specific antibody has identified DIGR1 in brain, head kidney, anterior intestine, liver, and gills of every larval and juvenile stages. The cytoplasmic versus nuclear distribution and the presumptive roles of GR-cortisol interaction in larval stages are discussed.

\section{Materials and methods}

Larval developmental stages

Dicentrarchus labrax post-hatching developmental stages were supplied by the fish farm "Ittica Mediterranea" (Petrosino, TP, Italy). According to Barnabé (1980), the following four different developmental stages were identified on the basis of morphological characters and days posthatching (dph): (1) pre-larvae (1-5 dph) with symmetric body, yolk sac, spines, and air bladder; (2) larvae (6-25 dph) with visible fin rays, straight notochord, opened mouth, and eye migration; (3) post-larvae (26-49 dph) characterized by independent movement and nourishment, completion of eye migration, notochord slanted dorsally; (4) juveniles (50 dph) with visible flakes and adult morphology.

\section{Histology}

The above-listed developmental stages were examined. Prelarvae at 1, 3, and $5 \mathrm{dph}$, larvae at 7, 12, 20, and $25 \mathrm{dph}$, post-larvae at 30,35 , and $45 \mathrm{dph}$, and juveniles were anesthetized with $0.05 \%$ MS222 (3-aminobenzoic acid ethyl ester; Sigma Aldrich) in seawater and fixed for $24 \mathrm{~h}$ in Bouin's solution. Horizontal and transverse sections were serially cut (microtome Leica RM2035) at 3 or $6 \mu \mathrm{m}$, according to the size of the larval stage, and examined under a light microscope (Leica DMRE). Tissues and cells were identified according to Zapata (1979), Grace and Manning (1980), Rossi et al. (1988), Padrós and Crespo (1996), Teitsma et al. (1998), Pfeiffer et al. (1999), and Wilson and Laurent (2002).

\section{Preparation of riboprobe and ISH}

Digoxigenin-11-UTP-labeled riboprobe (DIG-riboprobe; final concentration: $1 \mu \mathrm{g} / \mathrm{ml}$ or $100 \mathrm{ng}$ probe/slide) was used according to the manufacturer's instructions (Roche Diagnostic); it included the transcriptional activation domain DIGR1 cDNA (1.0-1,300 nucleotide sequence; Vizzini et al. 2007). No significant similarity with the GR transcriptional domain sequence reported by Terova et al. (2005) was found by BLASTN 2.2.17 (http://www.ncbi.nlm.nih.gov/BLAST/).

ISH assay was carried out according to Le Guellec (1998). Sections were deparaffined and rehydrated, washed in PBS-T $\left(1 \mathrm{M} \mathrm{Na}_{2} \mathrm{HPO}_{4}, 1 \mathrm{M} \mathrm{NaH}_{2} \mathrm{PO}_{4}, 1.5 \mathrm{M} \mathrm{NaCl}, \mathrm{pH}\right.$ 7.4 containing $0.1 \%$ Tween 20 ) and digested with proteinase $\mathrm{K}$ (Sigma; $1 \mu \mathrm{l} / \mathrm{ml}$ in PBS-T). The reaction was then blocked with a stop-solution containing $2 \mathrm{mg} / \mathrm{ml}$ glycine in PBS-T. After two washes with PBS-T, the sections were post-fixed with $4 \%$ formaldehyde in PBS-T for $30 \mathrm{~min}$. Pre-hybridization with hybridization solution consisting of $50 \%$ formamide, $50 \mu \mathrm{g} / \mathrm{ml}$ heparin, $500 \mu \mathrm{g} / \mathrm{ml}$ yeast tRNA, 
$0.1 \%$ Tween $20,5 \times$ standard sodium citrate (SSC: $0.15 \mathrm{M}$ $\mathrm{NaCl} / 0.05 \mathrm{M}$ sodium citrate, $\mathrm{pH}$ 7) was carried out for $1 \mathrm{~h}$ at $37^{\circ} \mathrm{C}$. Hybridization was performed with $15 \%$ riboprobe in hybridization solution overnight at $37^{\circ} \mathrm{C}$.

The sections were rinsed with PBS-T and washing solution $(0.3 \% 20 \times \mathrm{SSC}, 1 \%$ Tween 20 , in distilled water $)$, incubated at room temperature (r.t.) with horse serum $(2 \%$ in PBS-T) and with anti-digoxigenin-Fab-antibody (Roche; diluted 1:100 in the horse serum solution) for $1 \mathrm{~h}$ at r.t. Finally, the sections were incubated in a 5-bromo-4-chloro3-indolyl phosphate/nitro blue tetrazolium liquid-substrate system (BCIP/NBT, Sigma).

Control experiments were performed by using the corresponding sense cRNA $(1 \mu \mathrm{g} / \mathrm{ml})$. Four specimens from each developmental stage were examined.

\section{Anti-DlGR1 antiserum preparation}

Anti-DlGR1 polyclonal antibody was raised in rabbit by using the hydrophilic peptide designed from the deduced amino acid sequence of the transcriptional activation domain. The peptide (85-98 amino acid residues LEDHESRGLTRDQK) located in the N-terminal portion of the previously cloned DlGR1 (Vizzini et al. 2007) was selected by antigen-prediction programs and synthesized by SigmaGenosys (UK). The synthetic peptide sequence was coupled to a carrier protein (keyhole limpet hemocyanin) for immunization and was emulsified with incomplete Freund's adjuvant.

Specificity of the anti-DlGR1 antiserum with regard to peptide sequence

The amino acid sequence of the peptide used for producing the antibody, as aligned in FASTA 3 and BLAST P in the EMBL Gene Bank, showed no similarity with annotated fish protein sequences including the GR reported by Terova et al. (2005). Although the peptide sequence could only be taken as an indicator of the epitope structure, the lack of similarity between the peptide sequence and the known protein sequences minimized the possibility that antibody cross-reactions could take place.

Specificity of the anti-DIGR1-antiserum as shown by enzyme-linked immunosorbent assay

Enzyme-linked immunosorbent assay (ELISA) and competition-ELISA revealed that the polyclonal antibody was specific for the DlGR1 peptide. Peptide ELISA was conducted as described by Plagemann (2005). In brief, the wells of Nunc Maxisorp ELISA plates (Nunc, Denmark) were coated overnight with the peptide dissolved in carbonate buffer, $\mathrm{pH}$ 9.6, at $10 \mu \mathrm{g} /$ well. After peptide coating, the wells were rinsed with PBS-T and then incubated with blocking buffer composed of PBS, $0.5 \%$ Tween 20 , and $1 \%(\mathrm{w} / \mathrm{v})$ bovine serum albumin (BSA) for $1 \mathrm{~h}$ at r.t. and then with anti-DlGR1 antiserum diluted $(1: 1,000-1: 6,000)$ in blocking solution or with preimmune rabbit serum in blocking solution (generally 1:50-1:200) for $1 \mathrm{~h}$ at r.t. After being rinsed with PBS-T, the wells were incubated with peroxidase-conjugated anti-rabbit IgG (Sigma-Aldrich; diluted 1:1,000 in blocking solution) for $60 \mathrm{~min}$ at r.t., rinsed four times with PBS-T, and then incubated with o-phenylenediamine $(2 \mathrm{mg}$ in $0.1 \mathrm{M}$ sodium citrate, $\mathrm{pH} 4.0)$ substrate $(100 \mu \mathrm{l} /$ well $)$ for 15-30 $\mathrm{min}$. The peroxidase product was quantified by measuring absorbance at $492 \mathrm{~nm}$ with an automatic plate reader.

In order to check for antiserum specificity according to Plagemann (2005), the antibody binding to immobilized peptide was inhibited by DlGR1 peptide in solution (competition ELISA). The peptide-coated plates were prepared as above reported, and after PBS-T rinsing and treatment with blocking solution, they were incubated with $100 \mu \mathrm{l}$ antiserum diluted $1: 3,000$ or $1: 5,000$ in PBS-T containing the peptide $(10 \mu \mathrm{g} / \mathrm{well})$. The wells were rinsed three times with PBS-T, and the standard procedure was used as previously described.

\section{Immunohistochemical staining}

Sections were deparaffined, rehydrated, and pre-incubated for $2 \mathrm{~h}$ at r.t. with 5\% BSA (Sigma) in PBS-T and then treated at $4{ }^{\circ} \mathrm{C}$ overnight with the primary antibody in PBS-T. After exhaustive washings, anti-rabbit IgG bound to alkaline phosphatase (Sigma; secondary antibody diluted 1:10,000 in PBS-T) was added to the sections. Finally, the sections were washed and treated with the BCIP/NBT liquid-substrate system (Sigma) at r.t. The primary antibody (whole rabbit antiserum, $75 \mathrm{mg} / \mathrm{ml}$ protein content) was assayed at various dilutions (1:100-1:1,000) and finally used at 1:500.

Immunohistochemistry assays in which the primary antibody was omitted or substituted with preimmune rabbit antiserum were used as controls. In addition, competitive inhibition with the synthetic peptide was carried out with antiserum dilued 1:500 $(100 \mu \mathrm{l})$ in the presence of $10 \mu \mathrm{g}$ peptide. Four specimens from each developmental stage were examined.

\section{Results}

ISH with DIG-riboprobe

In the pre-larval phase ( $3 \mathrm{dph})$, the riboprobe was only detected in the cells of the lateral portion of optic tectum (Fig. 1a), whereas larvae, post-larvae, and juveniles 


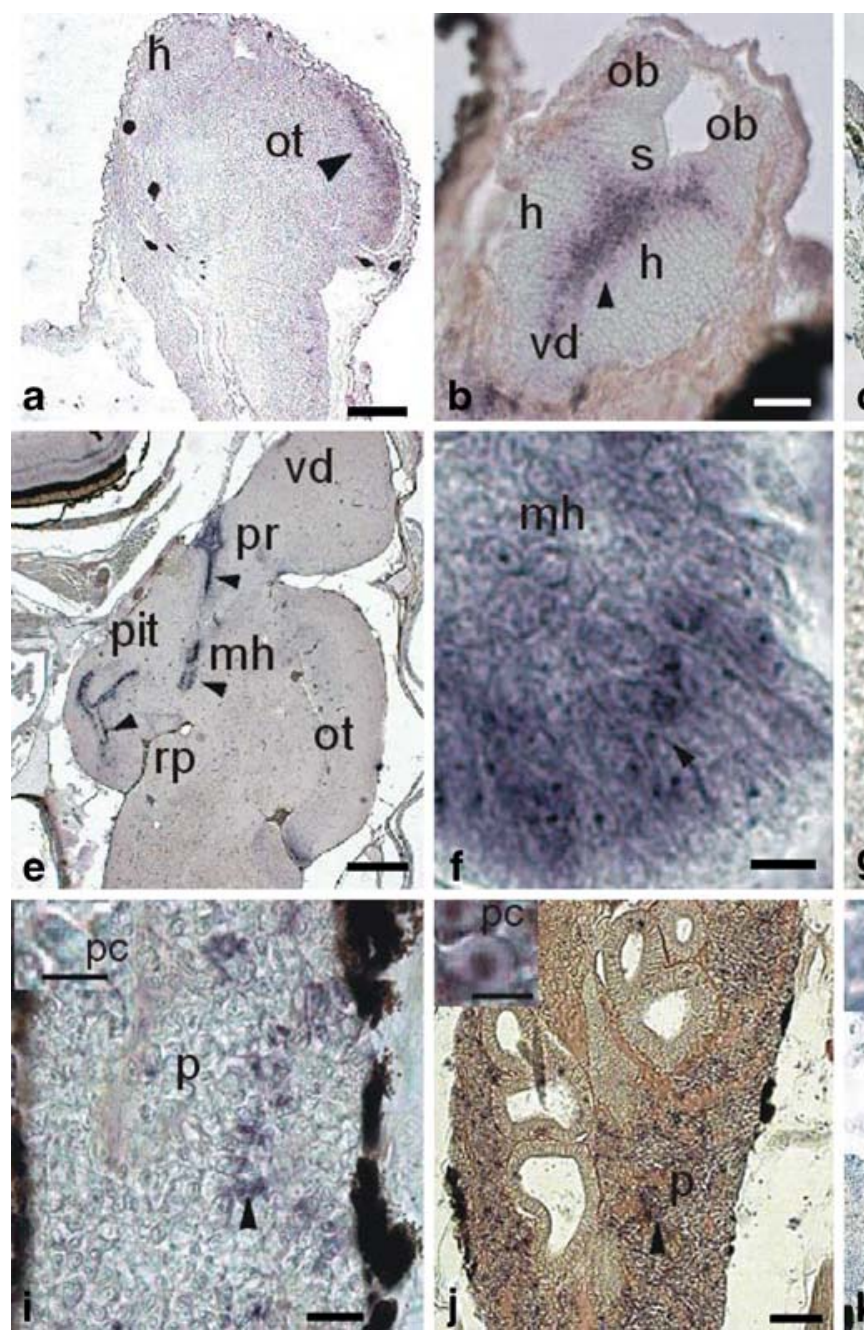

Fig. 1 Expression of a glucocorticoid receptor (DlGR1) in tissues of larval stages of sea bass (Dicentrarchus labrax). Horizontal sections (unless otherwise indicated). a-g, i, j, I In situ hybridization (ISH; black arrowheads) with DlGR1 riboprobe. h, k Immunohistochemistry (IH; black arrowheads) with anti-DlGR1 specific antibody. a Prelarva at $3 \mathrm{dph}$, optic lobe, ISH (ot optic tectum, $h$ @brain hemisphere). Bar $100 \mu \mathrm{m}$. b Larva at $10 \mathrm{dph}$, brain, ISH ( $h$ brain hemisphere, $v d$ area ventralis telencephali pars dorsalis, $s$ scissure, $o b$ olfactory bulb). Bar $100 \mu \mathrm{m}$. c Post-larva at $10 \mathrm{dph}$, sagittal section of brain, ISH $(t$ telencephalon, $p r$ preoptic region, $n p$ nucleus preopticus, $d$ diencephalon, $e$ eye). Bar $100 \mu \mathrm{m}$. d Post-larva at $30 \mathrm{dph}$, optic lobe, ISH (ot optic tectum). Bar $20 \mu \mathrm{m}$. e Post-larva at $50 \mathrm{dph}$, sagittal section of brain, ISH (pit pituitary gland, $p r$ preoptic region, $m h$ mediobasal
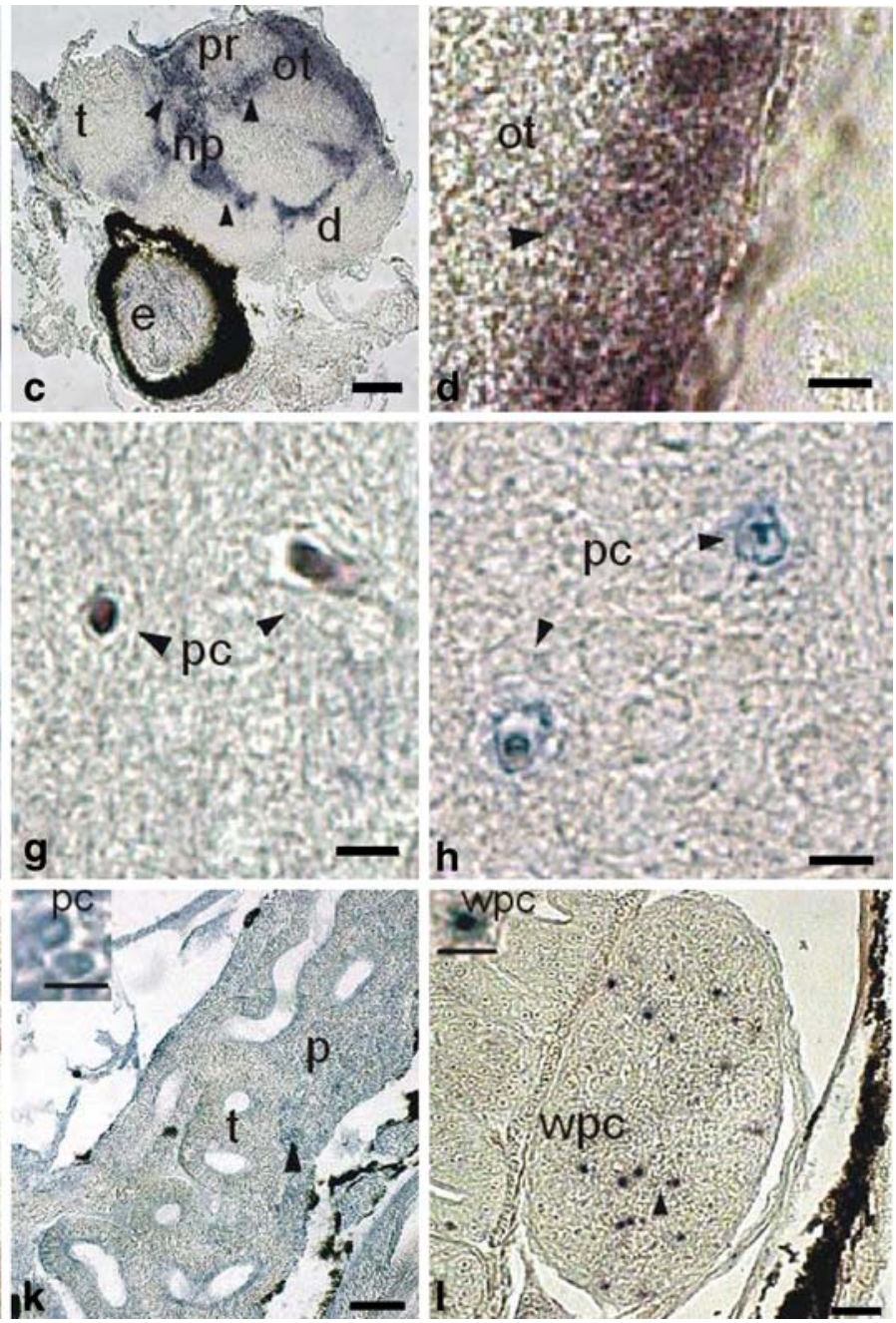

hypothalamus, ot optic tectum, $v d$ area dorsalis telencephali pars dorsalis, $r p$ posterior recess). Bar $250 \mu \mathrm{m}$. f Juvenile at $50 \mathrm{dph}$, detail of the mediobasal hypothalamus $(\mathrm{mh})$, ISH. Bar $20 \mu \mathrm{m}$. g Juvenile at $50 \mathrm{dhp}$, brain transverse section, ISH ( $p c$ pyramidal cell). Bar $20 \mu \mathrm{m}$. h Juvenile at $50 \mathrm{dph}$, brain transverse section, IH ( $p c$ pyramidal cell). Bar $20 \mu \mathrm{m}$. i Larva at $25 \mathrm{dph}$, head kidney, ISH ( $p$ parenchyma). Bar $40 \mu \mathrm{m}$. Inset: Parenchymatic cell $(p c)$. Bar $20 \mu \mathrm{m}$. j Juvenile at $50 \mathrm{dph}$, head kidney, ISH ( $p$ parenchyma). Bar $80 \mu \mathrm{m}$. Inset: Parenchymatic cell $(p c)$. k Juvenile at $50 \mathrm{dph}$, head kidney, IH ( $p$ parenchyma, $t$ tubule). Bar $80 \mu \mathrm{m}$. Inset: Parenchymatic cell (pc). Bar $25 \mu \mathrm{m}$. I Post-larva at $36 \mathrm{dph}$, spleen, ISH ( $w p c$ white pulp cells). Bar $60 \mu \mathrm{m}$. Inset: White pulp cell (wpc). Bar $20 \mu \mathrm{m}$

juveniles (50 dph), the riboprobe was additionally found in the rostral and proximal pars distalis of the pituitary gland (Fig. 1e), in the mediobasal hypothalamus (Fig. 1f), and in the pyramidal cells scattered throughout the brain (Fig. 1g).

Identification of the cytolocalization of the DIGriboprobe was difficult. However, in the pyramidal cells, it was found in the nucleus, whereas in the hypothalamus, it was localized both in the nucleus and cytoplasm.

In the parenchyma of the larval head kidney (12 dph), scattered cells contained the riboprobe in their nucleus 
(Fig. 1i). The hybridization effect became more evident at the juvenile stage (50 dph; Fig. 1j).

In the white pulp of the spleen, some nuclei contained the riboprobe in larvae at $20 \mathrm{dph}$ and in juveniles (Fig. 11).

In the larval anterior intestine (12 dph), the nucleus and the cytosol of columnar cells were marked by the riboprobe (not shown). Such localization was maintained in the juvenile phase (Fig. 2a).

The riboprobe was found in the nucleus of hepatocytes in the larval and post-larval liver (from $10 \mathrm{dph}$ ) and in juveniles additionally in the erythrocytes of sinusoids (Fig. 2c).

In the gills of $12 \mathrm{dph}$ larvae, undifferentiated cells of the primary lamellar epithelial tissue showed the riboprobe (Fig. 2e). Later (36 dph), it was manifest in the nucleus of several cell types including erythrocytes in the central venous sinus, chloride cells, epithelial cells of lamellae, and chondrocytes of the hypertrophic zone (Fig. 2f).

The DIG-riboprobe also stained the nucleus of erythrocytes in the blood vessels (Fig. 2c, f). Negative controls with the sense-strand probe gave no signal (not shown).

\section{Immunohistochemistry}

In larvae, post-larvae, and juveniles, the antibody identified DlGR1 in the head kidney, anterior intestine, liver, and gills.
In the brain, in spite of several attempts with various antibody dilutions $(1: 100-1: 1,000)$ and treatments of the sections in order to improve tissue permeabilization $(0.3 \%$ Triton $\mathrm{X}$ in PBS, or $0.5 \%$ Tween 20 in PBS at r.t. or at $37^{\circ} \mathrm{C}$ ), DIGR1 was only found in the cytosol and nucleus of pyramidal cells in juveniles (Fig. 1h) by using antiserum diluted 1:100.

The GR was present in the cytosol of the head kidney parenchyma cells (Fig. 1k), intestinal columnar cells (Fig. 2b), and hepatocytes (Fig. 2d).

In the larval gills $(20 \mathrm{dph})$, the immunohistochemical reaction stained chondrocytes of the hypertrophic zone, the respiratory epithelium, and chloride cells (Fig. $2 \mathrm{~g}$ ). In these last-mentioned cell types, the localization was cytosolic. In post-larvae (36 dph) and juveniles, DlGR1 was found in the cytosol of primary and secondary lamellae epithelial cells and chloride cells, and in the nucleus of chondrocytes (Fig. 2h).

Despite the above-reported attempts being carried out with various primary antibody dilutions and tissue permeabilizing treatments, the spleen sections of the examined developmental stages did not reveal any cell that reacted with the antibody.

Controls indicated that immunohistochemical staining was absent when the preimmune serum was used or
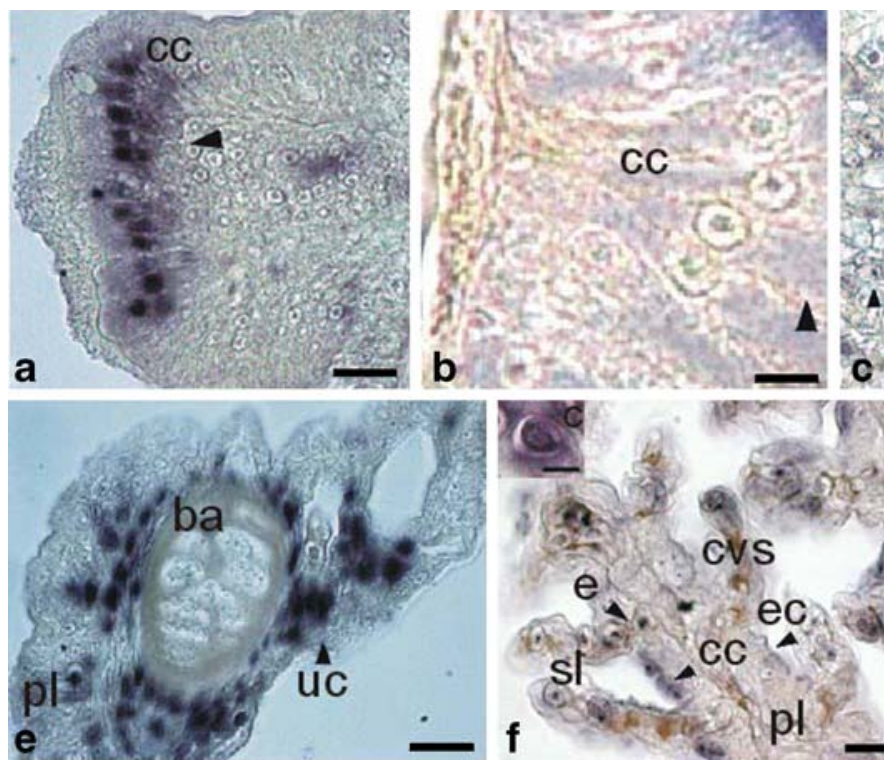

Fig. 2 Expression of a GR (DIGR1) in tissues of larval stages of sea bass (D. labrax). Horizontal sections (unless otherwise indicated). a, c, e, f In situ hybridization (ISH; black arrowheads) with DIGR1 riboprobe. b, d, g, h Immunohistochemistry (IH; black arrowheads) with anti-DlGR1 specific antibody. a Juvenile at $50 \mathrm{dph}$, anterior intestine, ISH ( $c c$ mucosa columnar cells). Bar $60 \mu \mathrm{m}$. b Juvenile at $50 \mathrm{dph}$, anterior intestine, IH (cc mucosa columnar cells). Bar $20 \mu \mathrm{m}$ c Juvenile at $50 \mathrm{dph}$, liver, ISH ( $s$ sinusoid, $h$ hepatocyte, $e$ erythrocyte). Bar $40 \mu \mathrm{m}$. Inset: Hepatocyte (h). Bar $20 \mu \mathrm{m}$. d Juvenile at $50 \mathrm{dph}$, liver, IH ( $h$ hepatocyte, $s$ sinusoid). Bar $100 \mu \mathrm{m}$. Inset: Hepatocyte $(h)$.
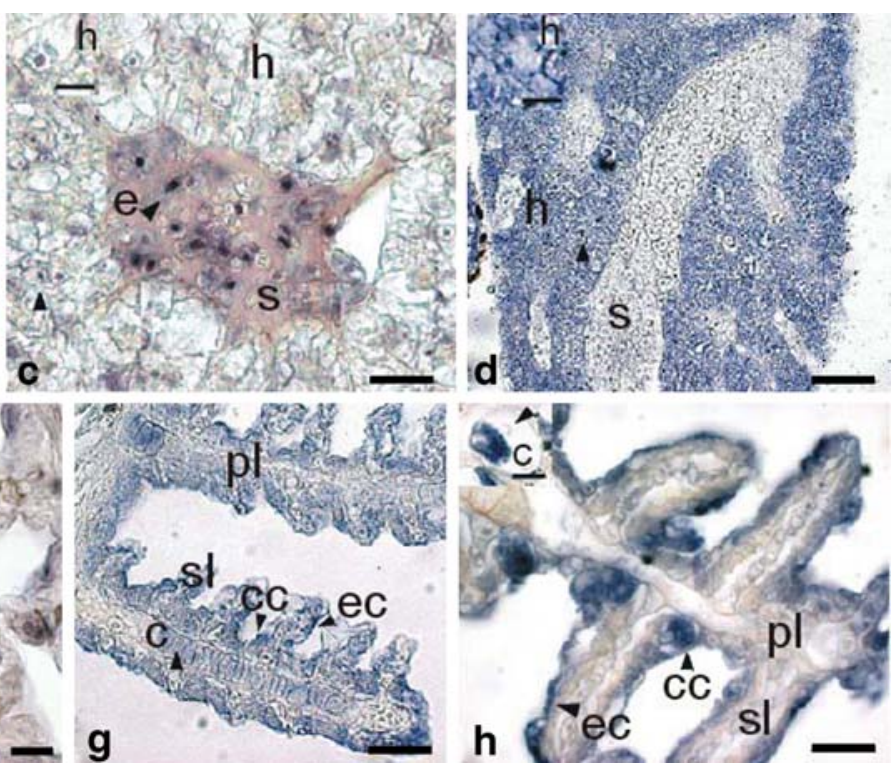

Bar $20 \mu \mathrm{m}$. e Larva at $12 \mathrm{dph}$, gills, ISH ( $u c$ undifferentiated cells, $b a$ branchial arch, $p l$ primary lamellae). Bar $60 \mu \mathrm{m}$. f Post-larva at $36 \mathrm{dph}$, gills, ISH ( $c v s$ central venous sinus, $s l$ secondary lamellae, $e c$ epithelial cells, $c c$ chloride cells, $e$ erythrocytes, $p l$ primary lamellae). Bar $40 \mu \mathrm{m}$. Inset: Chondrocyte (c). Bar $20 \mu \mathrm{m}$. g Larva at $20 \mathrm{dph}$, gills, IH (c chondrocyte, $e c$ epithelial cells, $c c$ chloride cells, $s l$ secondary lamellae, $p l$ primary lamellae). Bar $40 \mu \mathrm{m}$. h Post-larva at $36 \mathrm{dph}$, gills, IH ( $c c$ chloride cells, ec epithelial cells, $p l$ primary lamellae, $s l$ secondary lamellae). Bar $40 \mu \mathrm{m}$. Inset: Chondrocyte (c). Bar $20 \mu \mathrm{m}$ 
abolished when competitive inhibition of the primary antibody was performed (not shown).

\section{Discussion}

In fish ontogenesis, glucocorticoids are important regulators of metabolism, and cortisol is a critical hormone at the time of the first feeding when changes occur in the metabolic demands of the larvae, especially in terms of protein and carbohydrate metabolism (Ayson et al. 1995; Deane and Woo 2003; Szisch et al. 2005). Moreover, cortisol displays a synergistic role with thyroid hormones in inducing metamorphosis (de Jesus et al. 1991; Lam 1995). In Sparus sarba and Oncorhynchus keta larvae, cortisol increases between 1 and 7 dph but remains unchanged between 7 and $14 \mathrm{dph}$, reaching a peak between 35 and 46 dph (de Jesus and Hirano 1992; Deane and Woo 2003). Since the effects of glucocorticoid can be mediated through intracellular receptors, an examination of the expression and localization of GRs supporting genomic modulation pathway in developmental stages is of interest.

In D. labrax, a GR (DlGR1) has been cloned and sequenced from peritoneal cavity leukocytes, whereas in vitro assays with a GR blocker have shown that a cortisolGR interaction is involved in modulating phagocyte response via a genomic pathway (Vizzini et al. 2007). The high sequence similarity between DlGR1 and the GR reported by Terova et al. (2005) suggests that they are isoforms that significantly differ in their transcriptional activation domain.

To show that such a receptor is expressed even in sea bass post-hatching and juvenile stages, we have assayed DlGR1 (transcriptional activation domain) riboprobe and anti-DlGR1 antibody in pre-larvae, larvae and post-larvae histological sections. The presence of the riboprobe in the cell nucleus indicates endogenous synthesis of DlGR1 in brain, gills, head kidney, liver, and anterior intestine. The expression of the gene appears to be more evident in juveniles probably because of head kidney development and steroid/nuclear hormone receptor regulation mainly through the subcellular compartmentalization of ligandbound or non-ligand-bound receptor (Kumar et al. 2006; Bury and Sturm 2007).

The identification of the receptor with specific antibody has revealed the cytosolic and nuclear localization of DlGR1. A nuclear localization has been observed in pyramidal cells and in chondrocytes suggesting a nucleocytoplasmic shuttling of the protein. According to the model reported by Kumar et al. (2006), DlGR1 might occur in the cytoplasm in a complex with chaperon proteins capable of high-affinity binding to the ligand. This binding could lead to a conformational change in the receptor resulting in its dissociation from the chaperon or corepressor proteins, translocation into the nuclear compartment, and binding as a homodimer to cognate sites in steroid-responsive genes.

Although we have not examined the role of the GR of Terova et al. (2005) in the tissues and organs of the developmental stages of sea bass, results concerning DlGR1 expression and location suggest that GR is involved in several metabolic responses in accordance with the physiological role of cortisol in the organs and tissues of adult fish.

In the pre-larval $(3 \mathrm{dph})$ brain, the riboprobe is only detected in cells of the lateral portion of the optic tectum. In larval stages, DlGR1 expression appears to be increased, and the riboprobe is found in several regions of the brain. A similar immunohistochemical location of a GR in the forebrain of the adult rainbow trout $(O$. mykiss) has been reported by Teitsma et al. (1999). In adults, glucocorticoids are known to play a neuromodulatory role in the teleost central nervous system through cellular receptors, and sequential changes in cortisol and neurotransmitter release are coincident with increasing metabolic activities (Reid et al. 1996). Cortisol regulates the main neuronal populations of the caudal telencephalon/anterior preoptic region and diencephalon, which are involved in the regulation and secretion of gonadotropin GTH-I and GTH-II, and in juvenile fish cortisol affects the pituitary content of GTHII, presumably regulating the first sexual maturation (Huang et al. 1999). Moreover, the GR-mRNA in the preoptic area could be related to glucocorticoid effects in spawning behaviour (Satou et al. 1984; Shiga et al. 1985). The preoptic nucleus is known to contain corticotrophinreleasing factor-, vasotocin-, and isotocin-expressing cells (Teitsma et al. 1998). Finally, only juveniles show the DlGR1 protein in the nucleus and cytoplasm of pyramidal cells scattered in the brain. The possibility exists that, in earlier developmental stages, the amount of the synthesized protein is not sufficient for the antigen-antibody reaction in histological sections. As shown in the brain of adult Haplochromis burtoni in which differences in HbGR 1 and HbGR2 expression have been observed (Greenwood et al. 2003), a second GR (i.e., the GR reported by Terova et al. 2005) might be more markedly expressed than DlGR1 in $D$. labrax brain in the developmental stages (research in progress). Although, in mammals, brain cortisol is known to induce changes in hippocampal pyramidal cell morphology and pyramidal cell loss (Sapolsky et al. 1990; Watanabe et al. 1992; Starkman et al. 2001), the role of GR localization in fish pyramidal cells remains unclear.

In the examined developmental stages, the in situ hybridization and immunohistochemistry assays make it difficult to distinguish between head kidney red and white pulp. However, DlGR1 is probably expressed by macro- 
phages and neutrophils as in the adult (Vazzana et al. 2008). Likewise binding and competition studies with $\left[{ }^{3} \mathrm{H}\right]$ cortisol have shown that, in adult coho salmon, the GR is expressed in head kidney and spleen leukocytes (Maule and Schreck 1990). We have not been able to find DlGR1 in the spleen, even after the use of a variety of primary antibody dilutions and tissue permeabilization procedures. Although this result remains unclear, the possibility exists that, during spleen development, the amount of the synthesized protein is insufficient for the antigen-antibody reaction in an immunohistochemistry assay; on the other hand, both transcript and protein have been found in the white pulp of the adult spleen (Vazzana et al. 2008). GR in fish head kidney and spleen parenchyma has been related to an immunomodulatory glucocorticoid role (Werb et al. 1978; Maule and Schreck 1990).

Cortisol has a rapid effect on the phagocytic activity of leukocytes in head kidney (Stave and Roberson 1985; Vazzana et al. 2002), inhibiting the respiratory burst activity (Esteban et al. 2004).

In the columnar cells of the anterior intestine of larvae and juveniles, the location of the receptor might be associated with the roles of cortisol in, for example, hypoosmoregulation (Karnaki 1998; Takahashi et al. 2006), amino acid transport and nutrient reabsorption (Brown et al. 1991; Collie and Ferraris 1995), drug metabolism, and cell responses (Sheppard 2002).

The DlGR1 expression in the liver of larval, post-larval, and juvenile stages could be related to the key role of this organ in cortisol disposal. In addition, the liver is a target organ for the cortisol enhancement of glycolysis, gluconeogenesis, and fatty-acid synthesis rate (Freeman and Hidler 1973; Vijayan and Leatherland 1990).

In larval gills, the locations of transcript and protein (undifferentiated cells, chloride cells, erythrocytes, epithelial cells, and chondrocytes) are in accordance with the cortisol hypo-osmoregulatory role in early fish stages (Ayson et al. 1995; McCormick 1995; Seidelin et al. 1999; Pelis and McCormick 2001). Moreover, in mammals, the presence of GRs in the chondrocytes has been correlated with cell proliferation and differentiation (Abu et al. 2000).

The transcript has also been found in the nucleus of erythrocytes contained in liver sinusoids, gill central venous sinus, and blood vessels. In this respect, Pottinger and Brierley (1997) have detected cortisol-binding sites in rainbow trout erythrocytes, where cortisol may play a role in enhancing the erythrocyte sensitivity to catecholamine signals, under stress conditions, by increasing the internal pool of erythrocyte adrenoreceptors (Perry and Reid 1993; Grote et al. 1993).

Finally, contrary to the results obtained in the adult (Vazzana et al. 2008), spleen cells express DlGR1 mRNA, whereas we have not been able to reveal the presence of DlGR1 protein.
On the whole, the results reported here reveal the wide expression of a GR and diverse subcellular localization in tissues in the developmental stages of D. labrax. Moreover, the cytoplasmic versus nuclear distribution of the DlGR1 protein suggests that transcription modulation by the receptor may be imparted in response to interaction with its ligand. Further research is in progress to examine the expression and localization of the second GR of sea bass (Terova et al. 2005).

Acknowledgements We are grateful to Mr. G. Miceli (Department of Animal Biology, University of Palermo) and Dr. V. Balsamo (Mari. Consult. Trapani) for expert fish maintenance.

Open Access This article is distributed under the terms of the Creative Commons Attribution Noncommercial License which permits any noncommercial use, distribution, and reproduction in any medium, provided the original author(s) and source are credited.

\section{References}

Abu EO, Horner A, Kusec V, Triffitt JT, Compston JE (2000) The localization of the functional glucocorticoid receptor in human bone. J Clin Endocrinol Metab 85:883-889

Allison CM, Omeljaniuk RJ (1998) Specific binding sites for $\left[{ }^{3} \mathrm{H}\right]$ dexamethasone in the hypothalamus of juvenile rainbow trout, Oncorhynchus mykiss. Gen Comp Endocrinol 110:2-10

Ayson FG, Kaneko T, Hasegawa S, Hirano T (1995) Cortisol stimulates the size and number of mitochondrion-rich cells in the yolk-sac membrane of embryos and larvae of tilapia (Oreochromis mossambicus) in vitro and in vivo. J Exp Zool 272:419-425

Barnabé G (1980) Exposé synoptique des données biologique sur le loup ou bar Dicentrarchus labrax (Linné, 1758). FAO Fisheries Synopsis 126:1-70

Barry TP, Malison JA, Held JA, Parrish JJ (1995) Ontogeny of the cortisol stress response in larval rainbow trout. Gen Comp Endocrinol 97:57-65

Brown SB, MacLatchy DL, Hara TJ, Eales JG (1991) Effects of cortisol on aspects of 3,5,3'-triiodo-L-thyronine metabolism in rainbow trout (Oncorhynchus mykiss). Gen Comp Endocrinol $81: 207-216$

Bury NR, Sturm A (2007) Evolution of the corticosteroid receptor signalling pathway in fish. Gen Comp Endocrinol 153:47-56

Bury NR, Sturm A, Le Rouzic P, Lethimonier C, Ducouret B, Guiguen Y, Robinson-Rechavi M, Laudet V, Rafestin-Oblin ME, Prunet P (2003) Evidence for two distinct functional glucocorticoid receptors in teleost fish. J Mol Endocrinol 31:141-156

Collie NL, Ferraris RP (1995) Nutrient fluxes and regulation in fish intestine. In: Hochachka PW, Mommsen TP (eds) Biochemistry and molecular biology of fishes, vol 4. Metabolic biochemistry. Elsevier Science, Amsterdam, pp 221-239

de Jesus EG, Hirano T (1992) Changes in whole body concentration of cortisol, thyroid hormones, and sex steroid during early development of the chum salmon, Oncorhynchus keta. Gen Comp Endocrinol 85:55-61

de Jesus EG, Hirano T, Inui Y (1991) Changes in cortisol and thyroid hormone concentrations during early development and metamorphosis in the Japanese flounder Paralichthys olivaceus. Gen Comp Endocrinol 82:369-376 
Deane EE, Woo NYS (2003) Ontogeny of thyroid hormones, cortisol, hsp70 and hsp 90 during silver sea bream larval development. Life Sci 72:805-818

Ducouret B, Tujague M, Ashraf J, Mouchel N, Servel N, Valotaire Y, Thompson EB (1995) Cloning a teleost fish glucocorticoid receptor shows that it contains a deoxyribonucleic acid-binding domain different from that of mammals. Endocrinology 136: 3774-3783

Esteban MA, Rodríguez A, Meseguer J (2004) Glucan receptor but not mannose receptor is involved in the phagocytosis of Saccharomyces cerevisiae by seabream (Sparus aurata L.) blood leucocytes. Fish Shellfish Immunol 16:447-451

Feist G, Schreck CB (2002) Ontogeny of the stress response in chinook salmon, Oncorhynchus tshawytscha. Fish Physiol Biochem 25:31-40

Freeman HC, Hidler DR (1973) Effects of corticosteroid liver transaminases in two salmonids, the rainbow trout (Salmo gairdneri) and brook trout (Salvelinus fontinalis). Gen Comp Endocrinol 20:69-75

Grace MF, Manning MJ (1980) Histogenesis of the lymphoid organs in rainbow trout Salmo gairdneri. Dev Comp Immunol $4: 255-264$

Greenwood AK, Butler PC, White RB, DeMarco U, Pearce D, Fernald R (2003) Multiple corticosteroid receptors in a teleost fish: distinct sequences, expression patterns, and transcriptional activities. Endocrinology 144:4226-4236

Grote H, Ioannou I, Voigt J, Sekfris CE (1993) Localization of the glucocorticoid receptor in rat liver cells: evidence for plasma membrane bound receptor. Int Biochem 25:1593-1599

Huang Y-S, Rousseau K, Sbaihi M, Le Belle N, Schmitz M, Dufour S (1999) Cortisol selectively stimulates pituitary gonadotropin bsubunit in a primitive teleost, Anguilla anguilla. Endocrinology 40:1228-1235

Karnaki KJ (1998) Osmotic and ionic regulation. In: Evans DH (ed) The physiology of fishes, 2nd edn. CRC Press, New York, pp $157-176$

Kim BG, Brown CL (1997) Interaction of cortisol and thyroid hormone in the larval development of Pacific threadfin. Am Zool 37:470-481

Kumar S, Saradhi M, Chaturvedi NK, Tyagi RK (2006) Intracellular localization and nucleocytoplasmic trafficking of steroid receptors: an overview. Mol Cell Endocrinol 246:147-156

Lam TJ (1995) Possible roles of hormones in the control of egg over ripening and embryonic and larval development in fish. Asian Fisheries Soc Spec Publ 10:29-39

Le Guellec D (1998) Ultrastructural in situ hybridization: a review of technical aspects. Biol Cell 90:297-306

Lin GR, Weng CF, Wang JI, Hwang PP (1999) Effects of cortisol on ion regulation in developing tilapia (Oreochromis mossambicus) larvae on seawater adaptation. Physiol Biochem Zool 72:397-404

Maule AG, Schreck CB (1990) Glucocorticoid receptors in leukocytes and gills of juvenile coho salmon (Oncorhynchus kisutch). Gen Comp Endocrinol 77:448-455

McCormick SD (1995) Hormonal control of gill $\mathrm{Na}^{+}, \mathrm{K}^{+}$-ATPase and chloride cell function. In: Wood CM, Shuttleworth TJ (eds) Cellular and molecular approaches to fish ionic regulation. Academic Press, London, pp 285-315

Mommsen TP, Vijayan MM, Moon TW (1999) Cortisol in teleosts: dynamics, mechanism of action, and metabolic regulation. Fish Biol Fisheries 9:211-268

Padrós F, Crespo S (1996) Ontogeny of the lymphoid organs in the turbot Scophthalmus maximus: a light and electron microscope study. Aquaculture 144:1-16

Pelis RM, McCormick SD (2001) Effects of growth hormone and cortisol on $\mathrm{Na}^{+}-\mathrm{K}^{+}-2 \mathrm{Cl}^{-}$co-transporter localization and abundance in the gills of Atlantic salmon. Gen Comp Endocrinol 124:134-143
Plagemann PGW (2005) Epitope specificity of monoclonal antibodies to the N-protein of porcine reproductive and respiratory syndrome virus by ELISA with synthetic peptides. Vet Immunol Immunopathol 104:50-68

Perry SF, Reid SD (1993) B-adrenergic signal transduction in fish: interactive effects of catecholamines and cortisol. Fish Physiol Biochem 11:195-203

Pfeiffer CJ, Smith BJ, Smith SA (1999) Ultrastructural morphology of the gill of the striped bass (Morone saxatilis $\mathrm{x} M$. chrysops). Anat Histol Embryol 28:337-344

Pottinger T, Brierley L (1997) A putative cortisol receptor in the rainbow trout erythrocyte: stress prevents starvation-induced increases in specific binding of cortisol. J Exp Biol 200:2035-2043

Reid SG, Vijayan MM, Perry SF (1996) Modulation of catecholamine storage and release by the pituitary interrenal axis in the rainbow trout, Oncorhynchus mikiss. J Comp Physiol 165B:665-676

Rossi A, Bertolini B, Cataldi E, Cataudella S, Felici FR, Gentili G, Leoni C, Melotti P, Monaco G, Scorsini D, Sola L, Zacchei AM (1988) Anatomical atlas of the catfish (Ictalurus melas Raf.). Ministero Agricoltura e Foreste, Rome

Satou M, Oka Y, Kusunoki M, Matsushima T, Kato M, Fujita I, Ueda K (1984) Telencephalic and preoptic areas integrate sexual behavior in hime salmon (landlocked red salmon, Oncorhynchus nerka): results of electrical brain stimulation. Physiol Behav $33: 441-447$

Sapolsky RM, Stein-Behrens BA, Armanini MP (1990) Long-term adrenalectomy causes loss of dentate gyrus and pyramidal neurons in the adult hippocampus. Exp Neurol 1214:246-249

Seidelin M, Madsen SS, Byrialsen A, Kristiansen K (1999) Effects of insulin-like growth factor-I and cortisol on $\mathrm{Na}^{+} / \mathrm{K}^{+}$-ATPase expression in osmoregulatory tissues of brown trout (Salmo trutta). Gen Comp Endocrinol 113:331-342

Sheppard KE (2002) Nuclear receptor. II. Intestinal corticosteroid receptors. Am J Physiol Gastrointest Liver Physiol 282:742-746

Shiga T, Oka Y, Satou A, Okumoto N, Ueda K (1985) An HRP study of afferent connections of the supracommissural ventral telencephalon and the medial preoptic area in hime salmon (landlocked red salmon, Oncorhynchus nerka). Brain Res 361: 161-177

Starkman MN, Giordani B, Berent S, Schork MA, Schteingart DE (2001) Elevated cortisol levels in cushing's disease are associated with cognitive decrements psychosomatic medicine. Psychosom Med 63:985-993

Stave J, Roberson B (1985) Hydrocortisone suppresses the chemiluminescent response of striped bass phagocytes. Dev Comp Immunol 9:77-84

Stolte EH, Verburg van Kemenade BML, Savelkoul HFJ, Flik G (2006) Evolution of glucocorticoid receptors with different glucocorticoid sensitivity. J Endocrinol 190:17-28

Szisch V, Papandroulakis N, Fanouraki E, Pavlidis M (2005) Ontogeny of the thyroid hormones and cortisol in the gilthead sea bream, Sparus aurata. Gen Comp Endocrinol 142:186-192

Takahashi H, Sakamoto T, Hyodo S, Shepherd BS, Kaneko T, Grau EG (2006) Expression of glucocorticoid receptor in the intestine of a euryhaline teleost, the Mozambique tilapia (Oreochromis mossambicus): effect of seawater exposure and cortisol treatment. Life Sci 78:2329-2335

Takeo J, Hata J, Segawa C, Toyohara H, Yamashita S (1996) Fish glucocorticoid receptor with splicing variants in the DNA binding domain. FEBS Lett 389:244-248

Teitsma CA, Anglade I, Toutrirair G, Muñoz-Cueto J-A, Saligaut D, Ducouret B, Kah O (1998) Immunohistochemical localization of glucocorticoid receptor in the forebrain of the rainbow trout (Oncorhynchus mykiss). J Comp Neurol 401:395-410

Teitsma CA, Anglade I, Lethimonier C, Le Dréan G, Saligaut D, Ducouret B, Kah O (1999) Glucocorticoid receptor immunore- 
activity in neurons and pituitary cells implicated in reproductive functions in rainbow trout: a double immunohistochemical study. Biol Reprod 60:642-650

Terova G, Gornati R, Rimoldi S, Bernardini G, Saroglia M (2005) Quantification of a glucocorticoid receptor in sea bass (Dicentrarchus labrax, L.) reared at high stocking densitiy. Gene 357: 144-151

Vazzana M, Cammarata M, Parrinello N (2002) Confinement stress in sea bass (Dicentrarchus labrax) depresses peritoneal leukocyte cytotoxicity. Aquaculture 210:231-243

Vazzana M, Vizzini A, Salerno G, Di Bella ML, Celi M, Parrinello N (2008) Expression of a glucocorticoid receptor (DlGR1) in several tissues of the teleost fish Dicentrarchus labrax. Tissue Cell 40:89-94

Vijayan MM, Leatherland JF (1990) Cortisol-induced changes in plasma glucose, protein, and thyroid hormone levels, and liver glycogen content of coho salmon (Oncorhynchus kisutch Walbaum). Can J Zool 67:2746-2750

Vizzini A, Vazzana M, Cammarata M, Parrinello N (2007) Peritoneal cavity phagocytes from the teleost sea bass express a glucocor- ticoid receptor (cloned and sequenced) involved in genomic modulation of the in vitro chemiluminescence response to zymosan. Gen Comp Endocrinol 150:114-123

Watanabe Y, Gould E, McEwen BS (1992) Stress induces atrophy of apical dendrites of hippocampus CA3 pyramidal neurons. Brain Res 588:341-344

Werb Z, Foley R, Munck A (1978) Interaction of glucocorticoids with macrophages. J Exp Med 147:1684-1694

Wilson JM, Laurent P (2002) Fish gill morphology: inside out. J Exp Zool 293:192-213

Yeoh C-G, Schreck CB, Feist GW, Fitzpatrick M (1996) Endogenous steroid metabolism is indicated by fluctuations of endogenous steroid and steroid glucuronide levels in early development of the steelhead trout (Oncorhynchus mykiss). Gen Comp Endocrinol 103:107-114

Yudt M, Chidlowski JA (2002) Molecular identification and characterization of A and B forms of the glucocorticoid receptor. Mol Endocrinol 15:1093-1103

Zapata A (1979) Ultrastructural study of the teleost fish kidney. Dev Comp Immunol 3:55-65 